\title{
PENINGKATAN DURASI PEMBERIAN ASI PADA IBU POST PARTUM MELALUI RELAKSASI AUTOGENIC TRAINING
}

\author{
Farida Juanita $^{1 *}$, Suratmi $^{1}$ \\ 1. Program Studi Sarjana Keperawatan STIKES Muhammadiyah Lamongan, Lamongan 62200, Indonesia \\ *E-mail: faridajuanita@gmail.com
}

\begin{abstract}
Abstrak
Sebagian besar penyebab kegagalan menyusui berasal dari ketidakpercayadirian ibu. Salah satu intervensi yang dapat dilakukan untuk membantu keberhasilan menyusui adalah melalui autogenic training untuk mengurangi kecemasan dan meningkatkan kepercayaan diri ibu. Penelitian ini bertujuan untuk membuktikan bahwa ada pengaruh relaksasi autogenic training terhadap durasi menyusui. Penelitian ini menggunakan desain eksperimental posttest only - non equivalent control group design. Sampel sebanyak 30 diambil dari populasi yang memenuhi kriteria inklusi, dibagi menjadi kelompok kontrol dan perlakuan. Intervensi autogenic training dilakukan ibu di rumah selama 3 minggu. Posttest dilakukan home visite pada bulan pertama, ketiga dan keenam. Data dianalisis menggunakan one tailed independen $t$ test dengan $\alpha<0,05$. Hasil analisis menunjukkan bahwa kelompok perlakuan dapat memberikan ASI lebih lama dibandingkan kelompok kontrol $(\mathrm{p}=0,005)$. Dapat disimpulkan bahwa relaksasi autogenic training berpengaruh terhadap peningkatan durasi pemberian ASI. Penerapan hasil penelitian ini dapat dilakukan untuk membantu ibu untuk keberhasilan menyusui eksklusif.
\end{abstract}

Kata kunci: ASI, autogenic training, durasi menyusui, laktasi, relaksasi

\begin{abstract}
Increased Duration of Breastfeeding on Postpartum Mothers through Autogenic Training Relaxation. The failures of breastfeeding are mostly caused by mothers' inconfidence. Nurses can give psychological support by autogenic training relaxation which strengthens mothers' confidence to breastfeed exclusively. This method teaches mothers in building a positive intention and motivation to help the process of breastfeeding. This study aims to prove that autogenic training relaxation may expend the duration of breastfeeding. By using an experimental, posttest only - non equivalent control group design, 30 subjects are taken based on the criteria and divided into two groups. After providing autogenic training for 3 weeks, post-test conducted on the first, third and sixth months. Data were analyzed using one-tailed independent $t$ test with $\alpha=0.05$. The analysis showed that the intervention group could breastfeed longer than control group $(p=0.005)$. It can be concluded that autogenic training affected the duration of breastfeeding. These results can be considered that autogenic training as an intervention in support for exclusive breastfeeding.
\end{abstract}

Keywords: autogenic training, breastfeeding, duration, relaxation

\section{Pendahuluan}

Air Susu Ibu (ASI) merupakan makanan terbaik bagi bayi dari segi kandungan nutrisi, kebaikan untuk sistem pencernaan dan sistem immun, perkembangan fisik, psikis, dan interaksi antara ibu dan bayi (Nishioka, et al., 2011). Sebuah penelitian menyimpulkan bahwa bayi yang minum ASI terlindungi dari gangguan afektif dan disregulasi fisiologis aki- bat pengaruh ibu postpartum yang mengalami depresi (Jones, McFall, \& Diego, 2004). Menyusui juga mempunyai efek positif pada ibu, keluarga dan pencapaian kesehatan masyarakat melalui kebaikan nutrisi, imunologi, tumbuh kembang, psikologi, sosial ekonomi dan lingkungannya. Perlindungan, promosi dan dukungan terhadap ibu menyusui menjadi prioritas dalam program kesehatan masyarakat di semua negara (Vidas, Smalc, Catipovic, \& 
Kisik, 2011). Menyusui juga melindungi ibu dengan menginduksi ketenengan, mengurangi reaktifitas ibu untuk stres, dan meningkatkan perilaku nurturing. Menyusui akan melindungi ibu dari stres, dan menjaga suasana hati ibu (Tackett, 2007).

Saat terpenting waktu menyusui adalah pada beberapa hari pertama setelah melahirkan. Bila seorang ibu dibantu dengan baik pada saat ia mulai menyusui, kemungkinan ibu tersebut akan berhasil untuk terus menyusui (Siregar, 2004). Pada hakikatnya semua wanita dapat menyusui. Menurut WHO dalam MartinIglesias, et al., (2011), jarang ada wanita yang tidak dapat menyusui karena kelainan patofisiologis, diperkirakan $97 \%$ wanita subur mempunyai kemampuan untuk menyusui. Beberapa penyebab kegagalan menyusui juga telah diidentifikasi dari beberapa penelitian, yaitu kurangnya dukungan sosial, kontak yang kurang intensif antara ibu dan bayi, pengaruh sosial yang permisif terhadap pemberian susu formula atau penghentian menyusui, praktik komersil dari pabrik susu formula, pengenalan dini makanan pengganti ASI, pengetahuan yang kurang tentang menyusui pada ibu dan petugas kesehatan, kecemasan dan stres ibu, kurang percaya diri pada ibu untuk menyusui, berat badan bayi yang kurang, ibu malnutrisi, multi atau primipara, kontrasepsi hormonal dan temperamen bayi (Millan, Dewey, \& Escamilla, 2008).

Kegagalan dalam proses menyusui sering disebabkan karena timbulnya beberapa masalah, baik masalah pada ibu maupun pada bayi. Masalah dari ibu yang timbul selama menyusui dapat dimulai sejak sebelum persalinan (periode antenatal), pada masa pasca persalinan dini, dan pasca masa persalinan lanjut. Masalah menyusui dapat pula diakibatkan karena keadaan khusus seperti ibu mengeluhkan bayinya sering menangis atau menolak menyusu yang kemudian diartikan bahwa ASI tidak cukup atau tidak baik sehingga menyebabkan diambilnya keputusan untuk menghentikan menyusui (Widiasih, 2008). Rasa cemas yang disebabkan oleh perasaan takut tidak mampu menghasilkan ASI dan tidak memiliki ASI yang cukup adalah suatu alasan yang paling sering dikemukakan oleh ibu yang gagal mulai menyusui, berhenti menyusui terlalu cepat, atau memulai pemberian makanan tambahan sebelum makanan itu dibutuhkan. Dukungan psikologis dari keluarga, petugas kesehatan dan masyarakat akan memperkuat keyakinan diri ibu bahwa dia dapat berhasil menyusui (WHO, 2003). Kebutuhan ibu berupa akses informasi yang lebih jelas dari profesional kesehatan sejak periode antenatal sampai postnatal juga berpengaruh besar terhadap keberhasilan laktasi. Untuk mencapai inisiasi menyusui yang baik, ibu harus menerima bantuan profesional untuk cara menyusui selama jam-jam pertama kelahiran, dan pembelajaran praktis selama tinggal di rumah sakit (Kervin, Kemp, \& Pulver, 2010). Dari segi ketenagaan, harus dipastikan bahwa semua staf peduli pada ibu menyusui dan dapat menjawab semua pertanyaan ibu tentang menyusui (Condon \& Ingram, 2011). Peran dari petugas kesehatan memegang kunci penting untuk keberhasilan menyusui. Latar belakang budaya juga harus dipertimbangkan oleh petugas kesehatan untuk mengintervensi ibu menyusui. Ibu dapat diuntungkan dengan adanya dukungan menyusui untuk meningkatkan self efficacy dan perasaan mampu, kuat dan dapat menjadi ibu yang baik (Hannula, Kaunonen, \& Tarkka, 2008).

Di Indonesia, pemberian ASI eksklusif belum membudaya pada masyarakat termasuk di kalangan ibu bekerja (Purnamasari dan Rahardjo, 2007). Berdasar data penelitian dari Riset Kesehatan Dasar 2012, ibu yang berhasil memberi ASI secara eksklusif tercatat sebesar $61,5 \%$ pada tahun 2010. Sementara di Jawa Timur ibu yang memberi ASI sebesar $61,52 \%$ pada tahun 2011 dan Kota Surabaya berada dibawah rerata, yakni sebesar 26,88\% (Pusat Data dan Informasi Kementerian Kesehatan Republik Indonesia, 2012). 
Perawat sebagai salah satu bagian dari sistem kesehatan juga turut bertanggung jawab terhadap keberhasilan laktasi. Perawat turut berperan dalam mengatasi hambatan internal ibu dengan membantu mengatasi kecemasan ibu dan juga menjadi fasilitator kelompok pendukung ASI. Salah satu intervensi yang dapat dilakukan untuk membantu keberhasilan menyusui adalah melalui manajemen psikologis yaitu dengan mengajarkan ibu teknik relaksasi untuk mengurangi kecemasan dan meningkatkan kepercayaan diri ibu untuk dapat berhasil menyusui (Hannula, Kaunonen, \& Tarkka, 2008).

Penggunaan Autogenic Training (AT) untuk mendukung keberhasilan laktasi telah dilakukan di Kroasia. Ibu yang menyusui bayinya dilatih untuk melakukan AT sehingga dapat melakukannya di rumah tiga kali sehari. Pada tiap akhir latihan, ibu diberikan sugesti positif tentang menyusui seperti "Saya mencintai anak saya dan menyusuinya dengan penuh kenikmatan. Payudara saya indah, sehat dan kaya air susu. Air susu saya adalah makanan terbaik bagi anak saya. ASI dan jantung saya adalah nilai terbesar bagi anak saya. ASI dan ciuman kedamaian adalah anugrah dan pemberian cinta terindah untuk anak saya". Selanjutnya ibu meneruskan AT dirumah sampai 6 bulan usia bayi mereka. Hasil penelitian menyimpulkan bahwa ibu yang melakukan AT menunjukkan efek positif yaitu lebih stabil secara emosional, percaya diri yang lebih tinggi, serta menunjukkan durasi menyusui yang lebih lama dengan tingkat pemberian ASI eksklusif sampai 6 bulan yang lebih tinggi daripada kelompok kontrol. Hal ini menunjukkan bahwa ibu yang terelaksasi dan mempunyai percaya diri yang tinggi dapat lebih berhasil dalam proses laktasi (Vidas, Smalc, Catipovic, \& Kisik, (2011). Penelitian lain terkait penggunaan AT untuk keberhasilan menyusui menunjukkan bahwa AT berpengaruh tehadap keefektifan menyusui dan volume ASI (Juanita, 2013).
Desain atau rancangan penelitian ini menggunakan desain eksperimental jenis post test only-non equivalent control group design. Kelompok kontrol diambil dari pasien poliklinik/rawat jalan yang sedang kontrol postpartum atau kontrol bayi baru lahir, kemudian diikuti home visit saat bayi berusia 1 bulan, 3 bulan dan 6 bulan untuk dilakukan pengambilan data. Sedangkan kelompok perlakuan diambil dari pasien rawat inap yang baru melahirkan kemudian dilakukan intervensi. Pengajaran teknik relaksasi AT dilakukan setelah 24 jam ibu bersalin dan dilakukan di ruang rawat inap masing-masing pasien. Sebelum diberikan intervensi AT, dilakukan penjelasan kepada subjek peneltian tentang pengenalan AT, manfaat dan teknik pelaksanaan yang harus dilakukan oleh subjek peneltian dengan dibantu media modul atau leaflet. Peneliti kemudian melatih subjek penelitian untuk melaksanakan AT untuk selanjutnya dapat dilakukan sendiri dirumah oleh subjek peneltian. Setelah 1 bulan, 3 bulan dan 6 bulan postpartum, peneliti melakukan kunjungan rumah atau home visit untuk mengetahui apakah subjek penelitian masih memberi ASI tanpa tambahan makanan lain pada bayinya. Data yang sudah diolah dilakukan analisis perbedaan durasi menyusui antara kelompok perlakuan dan kelompok kontrol dengan menggunakan one tailed independen $t$ test dengan tingkat kemaknaan $\alpha<0,05$.

\section{Hasil}

Pengumpulan data didapatkan 30 subjek penelitian, masing-masing 15 subjek penelitian untuk kelompok kontrol dan 15 subjek penelitian untuk kelompok perlakuan. Berdasarkan wawancara yang dilakukan pada kelompok kontrol dan perlakuan didapatkan data mengenai karakteristik subjek penelitian meliputi usia ibu, pendidikan, pekerjaan, status gizi sebelum hamil (berdasar IMT), jenis persalinan dan berat badan bayi saat lahir yang disajikan dalam Tabel 1.

\section{Metode}


Berdasarkan observasi pemberian ASI selama bulan pertama, ketiga dan keenam pada kedua kelompok, didapatkan data sesuai Gambar 1 dan dilakukan uji menggunakan one tailed independent $t$ test yang disajikan pada Tabel 2. Pada Tabel 2 dapat diketahui bahwa subjek penelitian pada kelompok kontrol memiliki durasi pemberian ASI yang bervariasi, dengan durasi minimal 1 bulan dan durasi maksimal 6 bulan, didapatkan mean 3,2667 dengan standar deviasi sebesar 1,90738. Subjek penelitian pada kelompok perlakuan memiliki durasi pemberian ASI dengan durasi minimal 1 bulan dan durasi maksimal 6 bulan namun dengan rerata yang lebih tinggi, didapatkan mean 5,0667 dengan standar deviasi sebesar. Berdasar data tersebut terlihat bahwa sebagian besar kelompok perlakuan memiliki durasi pemberian ASI yang lebih lama jika dibandingkan dengan kelompok kontrol dengan $\Delta=-1,8000$. Hal ini juga dibuktikan melalui penghitungan analisis statistik dengan menggunakan independent $t$ test nilai hitung diperoleh sebesar -2,752 dengan $p=0,005$ (1-tailed), dengan demikian hipotesis diterima dan $\mathrm{H}_{0}$ ditolak.

Tabel 1. Karakteristik Subjek Penelitian Peningkatan Durasi Pemberian ASI pada Ibu Postpartum melalui Relaksasi Autogenic Training

\begin{tabular}{|c|c|c|c|c|c|}
\hline Karakteristik & $\begin{array}{c}\text { Kelompok } \\
\text { Kontrol }\end{array}$ & $\begin{array}{l}\text { Kelompok } \\
\text { Perlakuan }\end{array}$ & Frekuensi (f) & $\begin{array}{c}\text { Prosentase } \\
(\%)\end{array}$ & $\begin{array}{c}\text { Uji } \\
\text { Homogenitas }\end{array}$ \\
\hline \multicolumn{6}{|l|}{ Usia } \\
\hline a. $\leq 20$ tahun & 1 & 0 & 1 & 3,33 & \multirow{3}{*}{$\mathrm{p}=0,729$} \\
\hline b. $21-30$ tahun & 12 & 12 & 24 & 80 & \\
\hline c. $31-40$ tahun & 2 & 3 & 5 & 16,67 & \\
\hline \multicolumn{6}{|l|}{ Pendidikan } \\
\hline a. SMU & 1 & 2 & 3 & 10 & \multirow{3}{*}{$\mathrm{p}=0,487$} \\
\hline b.S1 & 11 & 11 & 22 & 73,33 & \\
\hline c. S2 & 3 & 2 & 5 & 16,67 & \\
\hline \multicolumn{6}{|l|}{ Pekerjaan } \\
\hline a. Pegawai negeri & 1 & 2 & 3 & 10 & \multirow{5}{*}{ - } \\
\hline b. Pegawai swasta & 6 & 7 & 13 & 43,33 & \\
\hline c. Dokter/ drg & 1 & 3 & 4 & 13,33 & \\
\hline d. Ibu rumah tangga & 5 & 2 & 7 & 23,33 & \\
\hline e. Mahasiswa & 2 & 1 & 3 & 10 & \\
\hline \multicolumn{6}{|l|}{ IMT } \\
\hline a. Underweight & 2 & 2 & 4 & 13,33 & \multirow{4}{*}{$\mathrm{p}=0,797$} \\
\hline b. Normal & 10 & 11 & 21 & 70 & \\
\hline c. Overweight & 3 & 1 & 4 & 13,33 & \\
\hline d. Obese & 0 & 1 & 1 & 3,33 & \\
\hline \multicolumn{6}{|l|}{ Persalinan } \\
\hline a. Normal/ spontan & 6 & 6 & 12 & 40 & \multirow{2}{*}{ Matching data } \\
\hline b. SC & 9 & 9 & 18 & 60 & \\
\hline \multicolumn{6}{|l|}{ BBL (gram) } \\
\hline a. $2500-3000$ & 7 & 6 & 13 & 43,33 & \multirow{3}{*}{$\mathrm{p}=0,720$} \\
\hline b. $3010-3500$ & 6 & 6 & 12 & 40 & \\
\hline c. $3510-4000$ & 2 & 3 & 5 & 16,67 & \\
\hline
\end{tabular}




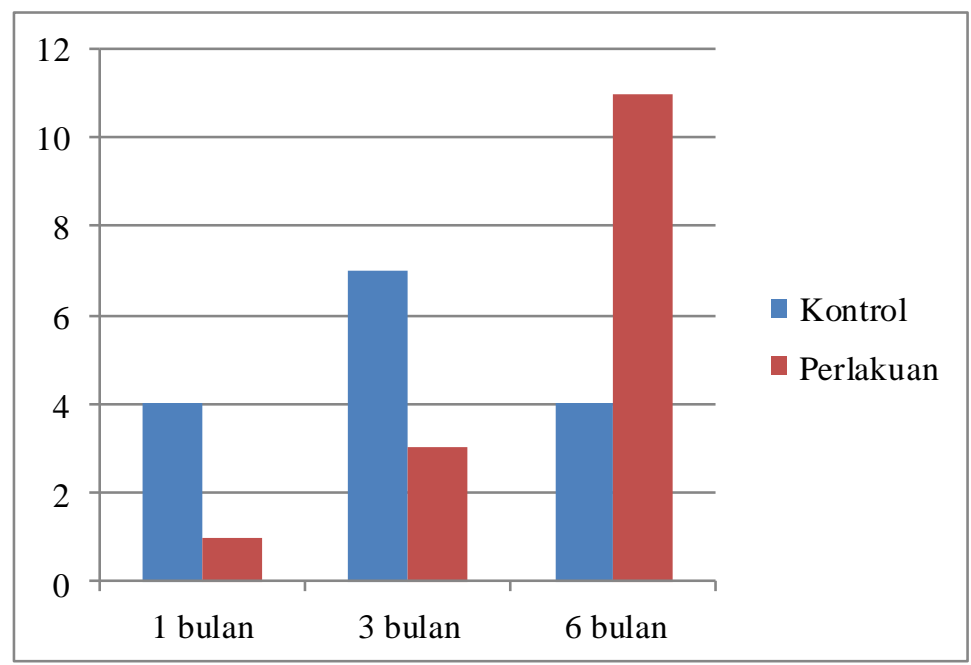

Gambar 1. Durasi Pemberian ASI Kelompok Kontrol dan Perlakuan

Tabel 2. Hasil Uji Analisis Independent T Test Durasi Pemberian ASI pada Ibu Postpartum melalui Relaksasi Autogenic Training

\begin{tabular}{lcccccc}
\hline \multicolumn{1}{c}{ Durasi } & n & Mean & SD & Min & Max & T test \\
\hline Kelompok kontrol & 15 & 3,2667 & 1,90738 & 1 & 6 & $\mathrm{t}=-2,752$ \\
Kelompok perlakuan & 15 & 5,0667 & 1,66762 & 1 & 6 & $\mathrm{p}=0,005(1$-tailed $)$ \\
& $\Delta$ & $-1,8000$ & & & & \\
\hline
\end{tabular}

\section{Pembahasan}

Usia merupakan salah satu faktor fisiologis yang secara langsung dapat memengaruhi proses pengeluaran ASI. Rentang usia 21-30 tahun merupakan usia produktif dan waktu yang tepat untuk hamil dan melahirkan serta merupakan usia yang paling baik dalam memproduksi ASI (Biancuzzo, 2003). Dalam penelitian ini, hampir seluruh subjek penelitian berada dalam rentang usia produktif untuk memproduksi ASI (subjek penelitian tertua berusia 32 tahun).

Pendidikan dan pekerjaan merupakan salah satu faktor yang secara tidak langsung memengaruhi laktasi terkait dengan latar belakang sosial budaya. Pendidikan berkaitan dengan kemampuan ibu untuk menerima informasi yang nantinya berpengaruh secara langsung dalam proses pengeluaran ASI. Faktor langsung yang terkait psikologis ibu meliputi persepsi ibu mengenai keuntungan dan kerugian menyusui dan pengetahuan tentang menyusui. Pekerjaan ibu berpengaruh secara tidak langsung pada proses laktasi, terkait dengan keterbatasan waktu ibu. (Bian-cuzzo, 2003). Berdasarkan data pada Tabel 1 sebagian besar subyek berpendidikan tinggi (S1) dengan distribusi yang sama antara kelompok kontrol dan perlakuan. Tingkat pendidikan dan pengetahuan mengenai ASI pada subjek penelitian hampir seluruhnya baik, terbukti dengan adanya motivasi untuk memberi ASI eksklusif pada bayinya. Selain itu, latar belakang pendidikan ini juga sangat membantu peneliti dalam memberikan intervensi pada kelompok perlakuan. Semua subjek peneltian kelompok perlakuan sangat kooperatif dan antusias dalam mengikuti program intervensi yang diberikan sehingga angka drop out minimal. Sebagian besar subyek bekerja sebagai pegawai swasta, namun berdasar wawancara pada subjek penelitian dalam penelitian ini, saat awal laktasi semua subjek peneltian yang bekerja sedang dalam masa cuti (rata-rata cuti hingga 3 bulan) 
dan seluruh subjek penelitian mempunyai orang yang membantu pekerjaan rumah sehingga faktor keterbatasan waktu ibu terkait pekerjaan dapat diabaikan.

Faktor fisiologis status kesehatan ibu, nutrisi, intake cairan merupakan faktor yang secara langsung dapat memengaruhi proses pengeluaran ASI. Dalam penelitian ini diambil data mengenai status gizi ibu sebelum hamil berdasarkan IMT. Hal ini dikarenakan status gizi orang dewasa cenderung konstan jika diukur melalui pengukuran anthropometri. Selain itu, berdasar wawancara, seluruh subjek peneltian tidak mempunyai pantangan makanan setelah melahirkan dan seluruh subjek peneltian juga mengkonsumsi diet tinggi kalori tinggi protein. IMT sebelum hamil juga akan berpengaruh terhadap inisiasi dan durasi menyusui (JM, 2011). Berdasarkan data pada Tabel 1 sebagian besar memiliki status gizi normal dan hanya 1 orang yang obese.

Kenyamanan ibu berkaitan nyeri insisi (post sectio caesar) merupakan salah satu faktor tidak langsung yang memengaruhi pengeluaran ASI. Persalinan dengan sectio caesar sangat berpengaruh terutama dalam inisiasi menyusui di hari-hari pertama postpartum jika dibandingkan dengan persalinan normal. Kesulitan memposisikan bayi, adanya nyeri insisi yang menyebabkan kesulitan mobilisasi ibu merupakan hal yang dapat menghambat pemberian ASI (Biancuzzo, 2003). Oleh karena itulah dalam penelitian ini dilakukan matching data pada jenis persalinan, sehingga bias dalam perbedaan keberhasilan menyusui dapat dimi-nimalkan.

Salah satu faktor tidak langsung dalam proses menyusui adalah faktor bayi yaitu berat badan bayi saat lahir, temperamen bayi dan status kesehatan bayi. Hubungan berat lahir bayi dengan volume ASI berkaitan dengan kekuatan untuk menghisap, frekuensi, dan lama penyusuan dibanding bayi yang lebih besar. Bayi yang dilahirkan semua subjek peneltian termasuk dalam kategori bayi normal dengan
APGAR skor baik dan BB antara 2500-4000 gram (bukan BBLR ataupun giant baby) sehingga faktor berat bayi lahir dianggap tidak berpengaruh terhadap variabel dependen.

Durasi pemberian ASI pada kelompok kontrol sebagian besar (7 dari 15 orang) adalah selama 3 bulan. Hal ini dimungkinkan berkaitan dengan pekerjaan ibu dimana sebagian besar merupakan wanita bekerja yang mendapat cuti melahirkan selama 3 bulan. Meski diawal pemberian ASI tidak terdapat perbedaan kesulitan untuk memulai memberikan ASI saat segera setelah melahirkan, namun diperkirakan kembalinya kesibukan ibu untuk bekerja bisa menimbulkan stres tersendiri bagi ibu, sehingga produksi ASI tidak lagi lancar. Hal tersebut sesuai dengan penelitian yang menyebutkan bahwa sebagian ibu di Basilicata dan Friuli Venezia Giulia melaporkan kesulitan menyusui berhubungan dengan kembalinya mereka bekerja dan ketidaktahuan akan hak menyusui bagi ibu pekerja (Romero, Bernal, Barbiero, Passamonte, \& Cattaneo, 2006). Alasan lain penghentian pemberian ASI dilaporkan penelitian lain berkaitan dengan produksi ASI yang sedikit, nyeri pada puting, dan keyakinan ibu bahwa bayi telah cukup umur untuk disapih (Lamontagne, Hamelin, \& St-Pierre, 2008).

Durasi pemberian ASI eksklusif berhasil dilakukan selama 6 bulan hanya pada 4 dari 15 orang kelompok kontrol. Semua ibu yang berhasil menyusui eksklusif selama 6 bulan ini benar-benar menikmati menjadi ibu baru yang dapat menyusui bayinya, bebas dari stres dan tidak mendapatkan kesulitan sama sekali dalam cara menyusui. Berdasar wawancara, semua ibu ini merasa senang dan mempunyai kepercayadirian yang tinggi untuk dapat menyusui eksklusif. Sesuai dengan teori bahwa prolaktin yang dihasilkan selama proses menyusui telah diteliti mempunyai efek relaksasi yang menyebabkan ibu menyusui merasa tenang bahkan mempunyai efek euforia sehingga semakin tinggi kadar prolaktin, dapat mencegah kejadian postpartum blues (Riordan $\&$ Auerbach, 2010). Menyusui juga melindu- 
ngi ibu dengan menginduksi ketenangan, mengurangi reaktifitas ibu untuk stres, dan meningkatkan perilaku nurturing sebagaimana penelitian yang membuktikan bahwa ketika menyusui berjalan dengan baik, kadar proinflammatory cytokine akan turun dalam batas normal sehingga hal ini akan melindungi ibu dari stres, dan menjaga suasana hati ibu (Tackett, 2007).

Pada kelompok perlakuan, durasi pemberian ASI eksklusif pada sebagian besar (11 dari 15 orang) adalah selama 6 bulan. Hal ini dimungkinkan disebabkan oleh beberapa faktor. Motivasi ibu untuk tetap meberikan ASI eksklusif mebuat ibu menghindari pemberian makanan tambahan pada bayi sebelum 6 bulan. Sebuah penelitian di Bolivia membuktikan bahwa menghindari pemberian makanan tambahan secara dini berhubungan dengan peningkatan lama menyusui (Ludvigsson, 2003). Ibu yang terbiasa memompa ASI juga terbukti mempunyai kecenderungan untuk dapat menyusui hingga 6 bulan meskipun pada penelitian ini tidak dikonfirmasi mengenai latar belakang budaya responden yang berkaitan dengan gaya hidup subyek penelitian (Win, Binns, Zhao, Scott, \& Oddy, 2006). Namun dari berbagai faktor tersebut, faktor utama yang memengaruhi keberhasilan menyusui eksklusif pada kelompok perlakuan adalah dari segi psikologis. Jika psikis ibu dalam kondisi baik, maka proses menyusui akan berjalan dengan baik pula sehingga transfer ASI dapat berjalan optimal.

Hasil analisis data menunjukkan adanya perbedaan durasi pemberian ASI yang signifikan antara kelompok kontrol dan perlakuan. Dengan telah mengendalikan beberapa faktor perancu yang mungkin berpengaruh pada hasil, hal ini berarti bahwa intervensi yang dilakukan peneliti berhasil memperpanjang durasi pemberian ASI pada kelompok perlakuan. Lamanya durasi pemberian ASI pada kelompok perlakuan ini diasumsikan terjadi karena dengan dilakukannya AT secara teratur, ibu akan mendapat efek psikologis yang positif, sehingga memperkuat keyakinan dirinya akan keberhasilan menyusui. Dengan pikiran yang positif dan rasa percaya diri yang tinggi, kemampuan ibu untuk menyusui secara efektif juga akan meningkat sehingga kesulitankesulitan menyusui dapat dengan mudah diatasi bahkan tidak dijumpai sama sekali.

Dalam penelitian sebelumnya, AT terbukti dapat memberikan efek menenangkan pikiran dan tubuh, dan dapat digunakan untuk mengobati kondisi medis yang terkait dengan stres (Kanji, dkk., 2006). Dalam intervensi pada kelompok ini, juga terbukti bahwa efek positif dari AT berhasil memperpanjang durasi pemberian ASI hingga 6 bulan.

AT dideskripsikan sebagai bentuk psikoterapi psikofisiologis dimana seseorang dapat mengkondisikan dirinya sendiri dengan menggunakan konsentrasi pasif dan beberapa kombinasi stimuli psikofisiologis yang disesuaikan dengan kebutuhan terapinya (formula autogenic). Dalam penelitian ini formula autogenic yang dimaksud adalah sugesti positif untuk keberhasilan laktasi. Hal ini melibatkan repetisi mental dengan menggunakan frase verbal yang singkat yang dimaksudkan untuk memperoleh sensasi tubuh yang spesifik seperti rasa berat dan kehangatan, bernafas rileks dan merasakan dahi dingin. Bila diterapkan dalam keadaan relaksasi, frase tersebut dapat memengaruhi alam bawah sadar secara mendalam. Dengan latihan yang terus-menerus yang akan menyebabkan korteks prefrontal dapat memperbaiki respons terhadap stres, AT dapat menanamkan keyakinan diri ibu untuk dapat menyusui secara efektif, sehingga berpengaruh pada durasi pemberian ASI eksklusif.

Penelitian ini memperkuat ribuan publikasi ilmiah sebelumnya yang memaparkan laporan mengenai efek yang menguntungkan dari AT yang membuatnya menjadi metode penyembuhan stres dan merupakan penelitian yang paling konsisten di seluruh dunia dengan level of evidence (LOE) tingkat 1 . Pengaruh positif AT pada penelitian ini juga menambah kajian 
yang mengeksplorasi aplikasi AT untuk ibu postpartum dalam hal dukungan menyusui. Hasil penelitian ini menambah efek positif lain AT terhadap laktasi yang pada penelitian sebelumnya terbukti efektif untuk meningkatkan skor keefektifan menyusui dan memperbesar volume ASI (Juanita, 2013), serta penelitian lain oleh Vidas, Smalc, Catipovic, \& Kisik (2011) yang membuktikan bahwa ibu yang melakukan AT menunjukkan efek lebih stabil secara emosional, percaya diri yang lebih tinggi, serta menunjukkan durasi menyusui yang lebih lama dengan tingkat pemberian ASI eksklusif sampai 6 bulan yang lebih tinggi daripada kelompok kontrol. Hal ini menunjukkan bahwa ibu yang terelaksasi dan mempunyai percaya diri yang tinggi dapat lebih berhasil dalam proses laktasi.

\section{Kesimpulan}

Hasil penelitian dapat disimpulkan bahwa relaksasi Autogenic Training terbukti berpengaruh terhadap peningkatan durasi pemberian ASI melalui penanaman sugesti positif untuk keberhasilan laktasi berupa repetisi frase atau kalimat positif yang diterima melalui sensori thalamus yang diteruskan ke korteks prefrontal dan amigdala dan tersimpan di memori hipokampus, sehingga ibu akan mempunyai respons yang lebih baik terhadap stres berupa peningkatan rasa percaya diri ibu untuk dapat menyusui secara efektif hingga 6 bulan. Berdasarkan hasil penelitian tersebut disarankan pada petugas kesehatan untuk merekomendasikan penggunaan AT untuk membantu ibu meningkatkan keberhasilan pemberian ASI eksklusif (TN, AM, INR).

\section{Referensi}

Biancuzzo, M. (2003). Breastfeeding the newborn: clinical strategies for nurses. London: Mosby.

Condon, L.C., \& Ingram, J. (2011). Increasing support for breastfeeding: What can Children's Centres do? Health and Social Care in the
Community, 19 (6), 617-625. doi: 10.1111/j $.1365-2524.2011 .01003 . x$.

Hannula, L., Kaunonen, M., \& Tarkka, M.T. (2008). A systematic review of professional support interventions for breastfeeding. Journal of Clinical Nursing, 17 (9), 11321143. doi: 10.1111/j.1365-2702.2007.02239.x.

JM, W. (2011, March). Maternal Prepregnancy Body Mass Index and Initiation and Duration of Breastfeeding: a Review of The Literature. $J$ Womens Health , 341-7. doi: 10.1089/jwh. 2010.2248 .

Jones, N.A., McFall, B.A., \& Diego, M.A. (2004). Patterns of brain electrical activity in infants of depressed mothers who breastfeed and bottle feed: The mediating role of infant temperament. Biological Psychology, 67 (1-2), 103-124. doi: http://dx.doi.org/10.1016/j.biop sycho.2004.03.010

Juanita, F. (2013). Relaksasi autogenic training untuk membantu keberhasilan masa awal laktasi pada ibu postpartum. Jurnal Ners, 8 (2), 283-294. ISSN 1858-3598

Kanji, N., White, A., \& Ernst, E. (2006). Autogenic training to reduce anxiety in nursing students: Randomized controlled trial. Journal of Advanced Nursing, 53 (6), 729-735. doi: 10.1111/j.1365-2648.2006.03779.x

Kervin, B.E., Kemp, L., \& Pulver, L.J. (2010). Types and timing of breastfeeding support and its impact on mother's behaviour. Journal of Paediatrics and Child Health, 46 (3), 85-91. doi: 10.1111/j.1440-1754.2009.01643.x.

Lamontagne, C., Hamelin, A.M., \& St-Pierre, M. (2008). The breastfeeding experience of women with major difficulties who use the services of a breastfeeding clinic: A descriptive study. International Breastfeeding Journal , 5 (3), 3-17. doi: 10.1186/1746-43583-17

Ludvigsson, J. F. (2003). Breastfeeding intentions, patterns, and determinants in infants visiting hospitals in La Paz, Bolivia. BMC Pediatrics, 3, 5. doi: 10.1186/1471-2431-3-5 
Martín-Iglesias, M., del-Cura-González, I., SanzCuesta, T., Argüelles, C.A., RumayorZarzuelo, M., Riva, M.A., Bravo, A.M.L., Férnandez-Arroyo, R.M.,...Cornejo-Gutiérrez, A.M. (2011). Effectiveness of an implementation strategy for a breastfeeding guideline in Primary Care: cluster randomised trial. BMC Family Practice, 12 (1), 144. doi: 10.1186/1471-2296-12-144.

Millan, S. S., Dewey, K. G., \& Escamilla, R. P. (2008). Factors Associated with Perceived Insufficient Milk in a Low Income Urban Population in Mexico. The Journal of Nutrition, 124 (2), 202-212. Diperoleh dari http://www.ncbi.nlm.nih.gov/pubmed/8308569

Nishioka, E., Haruna, M., Ota, E., Matsuzaki, M., Murayama, R.,...Yoshimura, K. (2011). A prospective study of the relationship between breastfeeding and postpartum depressive symptoms appearing at 1-5 months after delivery. Journal of Affective Disorders, 133 (3), 553-559. doi: 10.1016/j.jad.2011.04.027.

Purnamasari, D.U., \& Rahardjo, S. (2007). Pemodelan kuantitatif untuk analisis faktor penentu praktik pemberian ASI eksklusif pada ibu bekerja di Instansi Universitas Jenderal Soedirman Purwokerto. Purwokerto: Jurusan Kesehatan Masyarakat FKIK Universitas Jenderal Soedirman Purwokerto.

Pusat Data dan Informasi Kementerian Kesehatan Republik Indonesia. (2012). Profil kesehatan provinsi Jawa Timur Tahun 2010. Surabaya: Kementerian Kesehatan RI.

Riordan, J., \& Auerbach, K.G. (2010). Breastfeeding and human lactation. London: Jones and Bartlett Publishers International.

Romero, S.Q., Bernal, R., Barbiero, C., Passamonte, R., \& Cattaneo, A. (2006). A rapid ethnographic study of breastfeeding in the North and South of Italy. International Breastfeeding Journal, 1, 14. doi: 10.1186/17 46-4358-1-14
Siregar, A. (2004). Faktor-faktor yang mempengaruhi pemberian asi oleh ibu melahirkan. Medan: Fakultas Kesehatan Masyarakat Universitas Sumatra Utara.

Tackett, K.K. (2007). A new paradigm for depression in new mothers: The central role of inflammation and how breastfeeding and antiinflammatory treatments protect maternal mental health. International Breastfeeding Journal, 30 (2), 6. doi: 10.1186/1746-4358-26.

Vidas, M., Smalc, V.F., Catipovic, M., \& Kisik, M. (2011). The application of autogenic training in counseling center for mother and child in order to promote breastfeeding. Collegium Antropologicum , 35 (3), 723-731.

WHO. (2003). Protecting promoting and supporting breastfeeding: The special role of maternity services. A joint WHO/ UNICEF statement. Geneva: World Health Organization.

Widiasih, R. (2008). Masalah-masalah dalam Menyusui. Seminar Manajemen Laktasi (pp. 111). Bandung: Fakultas Ilmu Keperawatan Universitas Padjadjaran.

Win, N.N., Binns, C.W., Zhao, Y., Scott, J.A., \& Oddy, W. H. (2006). Breastfeeding duration in mothers who express breast milk: A cohort study. International Breastfeeding Journal, 1, 28. doi: 10.1186/1746-4358-1-28. 